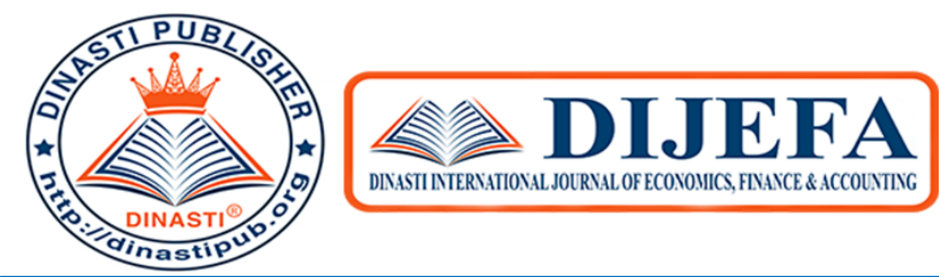

+6281387654578?

+6281387654578 (Q)

https://dinastipub.org/DIJEFA (-)

dinasti-info@gmail.com G.

\title{
STOCK PRICE INDEX (CSPI)IN INDONESIA STOCK EXCHANGE (IDX) PERIOD
} 2014-2018

\section{Said Djamaluddin ${ }^{\text {1) }}$, Riki Ardoni ${ }^{2)}$, Aty Herawati ${ }^{3)}$}

${ }^{1)}$ Postgraduate Lecturer, Mercubuana University, Jakarta, Indonesia

${ }^{2)}$ Postgraduate Alumni, Mercubuana University, Jakarta, Indonesia

${ }^{3)}$ Postgraduate Lecturer, Mercubuana University, Jakarta, Indonesia

\begin{tabular}{|c|c|}
\hline $\begin{array}{l}\text { ARTICLE INFORMATION } \\
\text { Received: } 25 \text { February } 2020 \\
\text { Revised: } 15 \text { March } 2020 \\
\text { Issued: } 23 \text { March } 2020 \\
\text { Corresponding author: } \\
\text { Said Djamaludin } \\
\text { E-mail: } \\
\text { Said_djamaluddin@mercubuana.ac.id } \\
\text { rikiardoni17@gmail.com }\end{array}$ & $\begin{array}{l}\text { Abstract: This study aims to determine the effect of } \\
\text { the BI rate, the dollar exchange rate, the yuan } \\
\text { exchange rate, the Dow Jones index, the Shanghai } \\
\text { index and world oil prices on the composite stock } \\
\text { price index (CSPI). The data used is the period from } \\
\text { January } 2014 \text { to December } 2018 \text { with the multiple } \\
\text { regression analysis method. The results showed that } \\
\text { the BI rate, Dollar Exchange, Yuan Exchange, Dow } \\
\text { Jones, SSE Composite Index and WTI were able to } \\
\text { explain the 91.8\% effect on CSPI and the remaining } \\
8.2 \% \text { explained by other variables not examined. T } \\
\text { test results show that partially BI interest rates, the } \\
\text { yuan and Shanghai exchange rates do not have a } \\
\text { significant effect on CSPI. While the dollar exchange } \\
\text { rate, Dow Jones Index and world crude oil prices have } \\
\text { a significant influence on the composite stock price } \\
\text { index (CSPI) with coefficients respectively - 0.41705, } \\
+0.21245 \text { and - } 7.86373 \text {. The independent variable that } \\
\text { has the most dominant influence on CSPI is Crude Oil } \\
\text { (WTI). } \\
\text { Keywords: Dollar Exchange Rate, Yuan Exchange } \\
\text { Rate, Dowiones Index, Shanghai Index, WTI. }\end{array}$ \\
\hline
\end{tabular}

\section{INTRODUCTION}

Stock price index is one indicator that describes the movement of stock prices. Index becomes one of the guidelines for investors in considering investing in the capital market, especially stocks. The Composite Stock Price Index (CSPI) uses all listed companies as a component of index calculation. At the moment some issuers are not included in the CSPI calculation, for example ex-Surabaya Stock Exchange issuers for reasons of not (or not yet) transaction activity so prices have not been created in the market. According to Tandelilin (2010: 86) CSPI is an index that uses all stocks listed as price index calculations. If the CSPI 
shows an increase, it indicates that the condition of the Indonesian economy is in a cycle of improvement and vice versa.

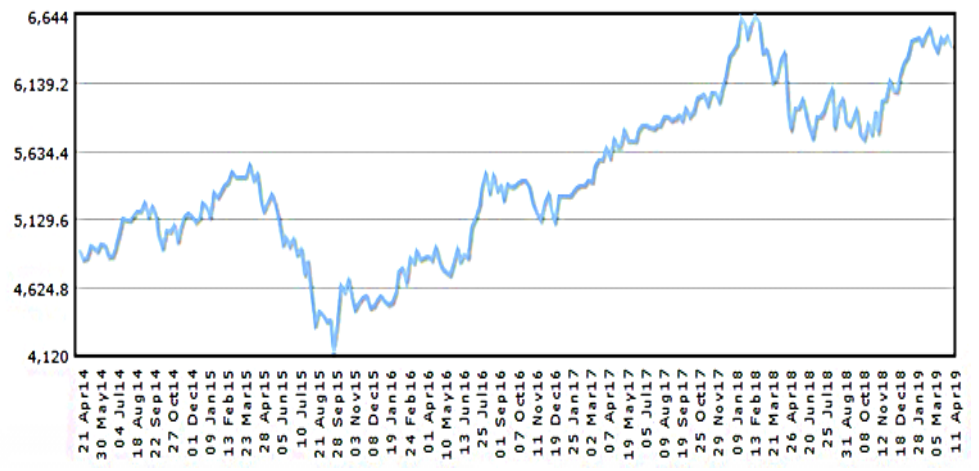

Figure 1.1. JCI Graph in the Last 5 Years.

From the results of chart observations, researchers found that the Composite Stock Price Index experienced a sharp decline in 2018.

For the United States the index that can be used as a proxy is the Dow Jones Index. The Dow Jones Index is the oldest stock market index in the United States and is a representation of the performance of the most important industries in the United States (www.nyse.com). Companies listed on the Dow Jones Index are generally multinational companies. Their operations are spread all over the world. Companies such as Coca-Cola, ExxonMobil, Citigroup, Procter \& Gamble are examples of companies listed on Dow Jones and operating in Indonesia (www.kompas.com). These companies generally operate directly in Indonesia.

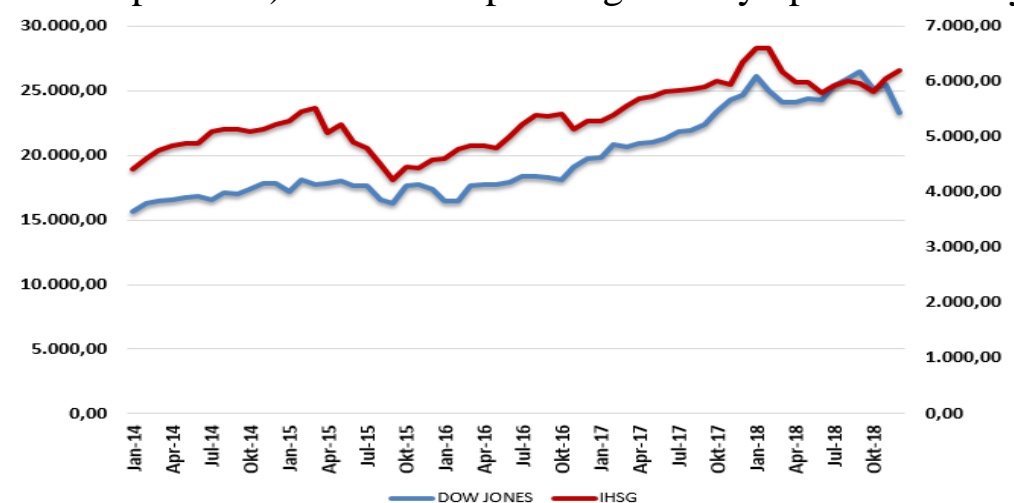

Figure 1.2. CSPI and Dow Jones charts period 2014-2018

From the graphic image above, it can be seen that the rise in the CSPI has succeeded in rising the Dow Jones index, so researchers conclude that the Dow Jones has a positive effect.

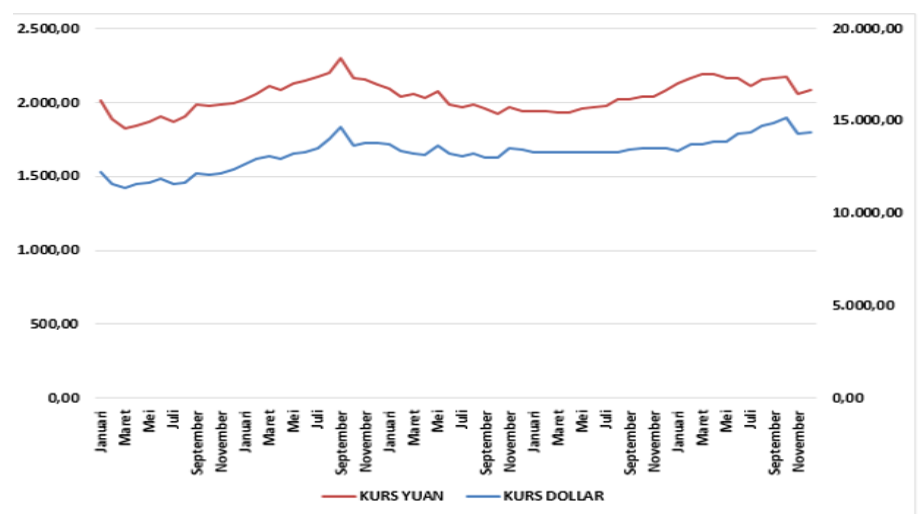

Figure 1.3. Graph of Dollar and Yuan Exchange Rates. 
From the graph above, researchers see a positive influence between the dollar and the yuan. So that researchers suspect that the exchange rate of the dollar and yuan has a positive effect on the CSPI.

The Chinese economy has become one of the most influential countries in the world. And China is the main destination for Indonesian exports.

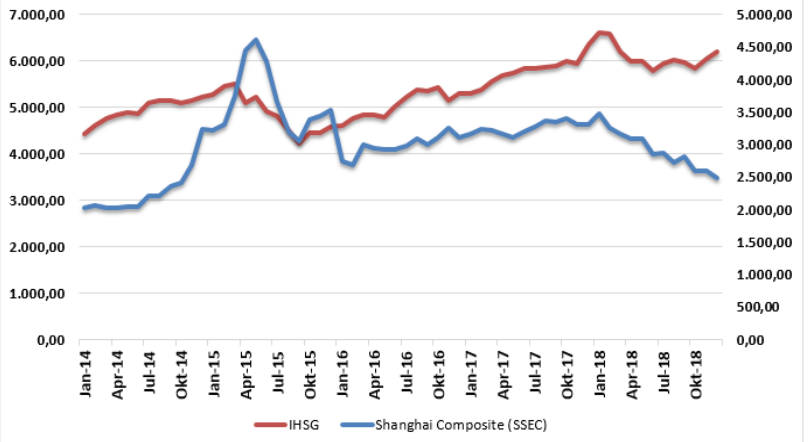

Figure 1.4. SSE Composite Index and IHSG charts

From the graphic image above, the IHSG has seen an increase over 2018 from the previous year, while the Shanghai index has tended to decline as the tariff war between the Chinese and American bamboo curtain countries.

Fluctuating global crude oil price movements are an indication that affects a country's capital market. The increase in world crude oil prices will indirectly affect the country's export and import sectors. For oil exporting countries, rising world crude oil prices are a distinct advantage for companies. Because oil prices are currently high, investors tend to invest their funds in various oil and mining commodity sectors. However, if oil prices are down, investors tend to seek profits by selling their shares. Rusbariand et. al (2012).

In connection with the influence of macroeconomic variables, one of the variables affecting the capital market is the level of world energy prices (Blanchard, 2006). The level of energy prices plays an important role in the Indonesian economy and stock market. This is based on the fact that on the Indonesia Stock Exchange, the capitalization value of mining companies listed on the composite stock price index (CSPI) reached 13.9\% (www.idx.co.id). The following researchers present a Chart of World Crude Oil Prices (WTI Crude Oil) during the 2014-2018 research period:

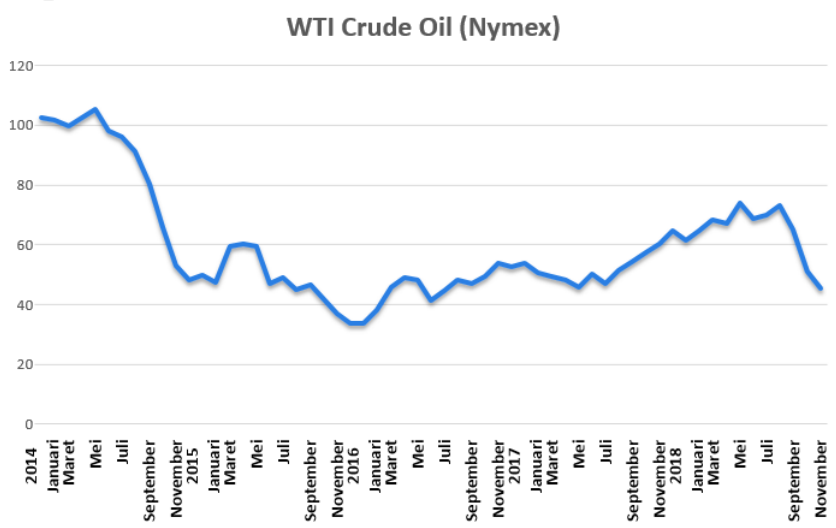

Figure 1.5. World Crude Oil Price Chart (WTI Crude Oil). 


\section{LITERATURE REVIEW}

\section{Macro Economics}

Macroeconomics or macroeconomics is a part of economics that studies the whole economic problem (aggregate). Macroeconomics studies the economic conditions of a society / country such as unemployment, employment opportunities, state expenditure, national income, interest rates, exchange rates / exchange rates, and so on. (Rini Astuti: 2016).

\section{Signaling theory}

According to Brigham and Hauston the cue or signal is an action taken by the company to give instructions to investors about how management views the company's prospects. This signal is in the form of information about what has been done by management to realize the wishes of their owners. Signals or signals are actions taken by company management that give instructions to investors about how the future management of the company's prospects (Brigham and Ehrhardt: 2005).

\section{Capital Asset Pricing Model}

The Capital Priet Asset Model (CAPM) assumes that investors are planners in a period that have the same perception about the state of the market and look for an average variant of the optimal portfolio. The Capital Asset Pricing model also assumes that the ideal stock market is a large stock market and investors are price takers, there are no taxes or transaction costs, all assets can be traded in general, and investors can borrow an unlimited amount at a fixed price. risk free rate. With this assumption, all investors have portfolios with identical risks. The Capital Priet Asset Model (CAPM) states that in equilibrium, market portfolios intersect with the average variant of the portfolio.

\section{Arbitrage Pricing Theory (APT)}

APT basically uses the idea that two investment opportunities that have the same identical characteristics cannot be sold at different prices. The concept used is the law of one price (the law of one price). If the assets with the same characteristics are sold at different prices, then there will be an opportunity to arbitrage by buying low-priced assets and at the same time selling them at a higher price so as to obtain a profit without risk. (Puspita: 2019).

\section{Contagion Effect}

Contagion or contagious effect is a phenomenon when a financial crisis that occurs in one country will trigger a financial or economic crisis in another country. Contagion theory states that no country in an area can escape the contagious effect. Contagion is a situation where a financial crisis is triggered by a financial crisis that occurs in another place or in other words from one institution spreads to other institutions (such as one bank spreads to another bank, or currency / stock market crashes in one country spreads to other countries).

\section{Composite Stock Price Index}

The Jakarta Composite Index or JSX Composite is one type of index that is on the Indonesia Stock Exchange. CSPI is to measure the performance value of all shares listed on a stock exchange by using all shares listed on the stock exchange as a component of index calculation. CSPI is used to determine the development and general situation of the capital market, not the situation of certain companies. This index covers the price movements of all common shares and preferred shares listed on the IDX. 
Effects of BI Rate, Dollar Exchange, Yuan Exchange, Shanghai Index, Dowjones Index and World Oil Prices

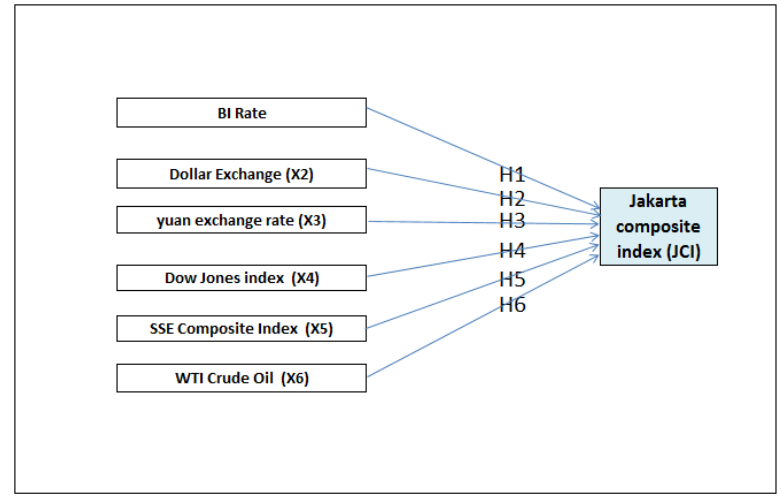

Figure 2.1. Research thinking framework.

From the picture above can be discussed above below: This research discusses the independent variables consisting of the BI 7 Day Repo Rate, Dollar Exchange Rate, Yuan Exchange Rate, Dow Jones Index, Shanghai Index, and World Crude Oil (WTI) on the dependent variable namely the Composite Stock Price Index (CSPI).

\section{RESEARCH METHODS}

This research is a quantitative approach that is associative, that is, a study conducted to find the relationship between one variable with another. The data used is secondary data from Time Serries, sourced from the official site Investing.com.

In this author's research, the independent variables studied were BI 7 Day Repo Rate, Dollars Exchange Rate, Yuan Exchange Rate, Dow Jones Index, Shanghai Index, and World Crude Oil (WTI).

The dependent variable in this study is the composite stock price index (CSPI) on the Indonesia Stock Exchange (IDX).

The price that will be used in this study is the closing price, the final price of a stock trading transaction that ends every month from January 2014 to December 2018. The data will be analyzed using Eviews software version 10. Functional relationship between independent variables with the dependent variable can be done with multiple regression. The analytical method used is linear regression model as follows:

$$
\mathrm{Y}=\mathrm{c}+\mathrm{b}_{1} \mathrm{X}_{1}+\mathrm{b}_{2} \mathrm{X}_{2}+\mathrm{b}_{3} \mathrm{X}_{3}+\mathrm{b}_{4} \mathrm{X}_{4}+\mathrm{b}_{5} \mathrm{X}_{5}+\mathrm{b}_{6} \mathrm{X}_{6}+\mathrm{e}
$$

With the information:

$\mathrm{Y}=$ Composite Stock Price Index (CSPI)

$\mathrm{c}=$ Constant

b1, b2, b3, b4, b5, b6 = regression coefficients

$\mathrm{X} 1=\mathrm{BI}$ Rate

$\mathrm{X} 2=\mathrm{USD}$ dollar exchange rate

$\mathrm{X} 3=$ YUAN exchange rate

$\mathrm{X} 4$ = Dow Jones Index

$\mathrm{X} 5$ = Shanghai Index

X6 $=$ World Crude Oil Price (WTI)

$\mathrm{e}=$ error 


\section{FINDINGS AND DISCUSSION}

\section{Statistical Descriptive Analysis.}

Based on data at investing.com, a report on BI 7 Day interest rates, Dollar and Yuan exchange rates, Dow Jones index, Shanghai Index, WTI Crude Oil and CSPI for 5 years from 2014 to 2018 will be presented as following:

Table 4.1. Display of Descriptive Statistics Results.

\begin{tabular}{llllc} 
& Maximum & Minimum & Std. Dev. & Observations \\
\hline IHSG & $6.605,63$ & $4.223,9100$ & 582,4147 & 60 \\
BI & 0,0775 & 0,0425 & 0,0135 & 60 \\
DOLLAR & $15.202,50$ & $11.360,0000$ & 867,1493 & 60 \\
YUAN & $2.304,51$ & $1.827,1900$ & 106,2258 & 60 \\
DJ & $26.458,31$ & $15.698,8500$ & $3.283,7730$ & 60 \\
SHANGHAI & $4.611,74$ & $2.026,3600$ & 552,6655 & 60 \\
WTI & 105,37 & 33,6200 & 19,2892 & 60 \\
\hline
\end{tabular}

Based on Table 4.1. above can be seen with the number of data $(\mathrm{N})$ of 60 months from January 2014 to December 2018, the highest JCI (maximum) at 6605,630 which occurred in January 2018. Meanwhile, the lowest (minimum) CSPI of 4223,910 which occurred in the month September 2015. BI has the highest value of 0.0775 that occurred in December 2014January 2015 and the lowest 0.0425 in September 2017 to April 2018. Variable Dollar has the highest value of 15202.50 which occurred in October 2018 and the lowest value of 11360.00 that occurred in March 2014. Variable Dollar Yuan with the highest value of 2304.51 that occurred in September 2015 and the lowest of 1827.19 that occurred in March 2014. The Dow Jones variable has the highest value of 26458.31 which occurred in September 2018 and the lowest of 15698.85 which occurred in January 2014. The Shanghai variable has the highest value of 4611.74 which occurred in May 2015 and the lowest of 2026.36 in b ulan april 2014. Whereas the WTI variable had the highest value of 105.37 which occurred in June 2014 and the lowest was 33.62 which occurred in January 2016.

\section{Regression Model Estimation}

The following display the regression equation in this study:

$\mathrm{IHSG}=6530.38890-2709.85218(\mathrm{BI}$ rate $)-0.41705$ (dollar exchange rate $)+0.31767$ (yuan exchange rate $)+0.21245$ (DowJones) +0.04121 (SSE Composite Index $)-7.86373$ $(\mathrm{WTI})+\mathrm{e}$

\section{Data Stationarity Test}

In this study the method used for data stationarity test is to use the unit root method. By looking at the Prob value of 0.6672 greater than 0.05 , the unit root test results state that the data is not stationary. So that further analysis is needed for the transformation of nonstationary time series into stationary by means of differentiation. The results of the first difference are as follows: 


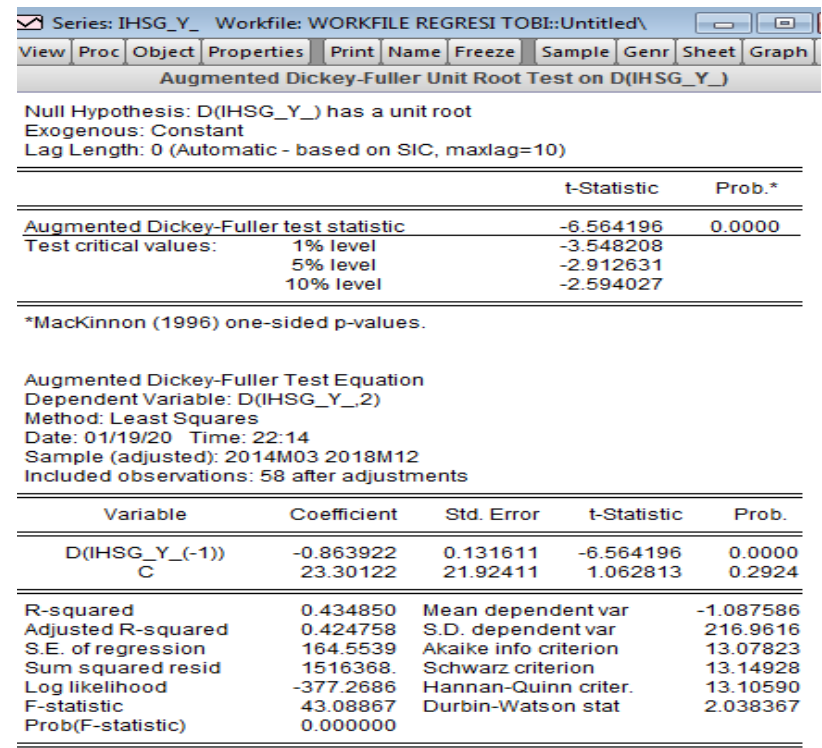

Figure 4.2. Unit root test results at the first differentiation level

The picture above shows the data is stationary (Prob value $<0.05$ ). In the same way a stationary test was performed on other variables and the results were obtained that all other independent data were stationary at the first differentiation level with a $\mathrm{p}$ value of 0,000 . Therefore it can be concluded that this research data has been stationary at grade 1 (d-1).

\section{Hypothesis test}

The accuracy of the sample regression function in estimating the actual value can be measured from Goodnees of fit. Statistically it can be measured from the coefficient of determination, the statistical value of $F$ and the statistical value of $t$.

Table 4.2. Hypothesis test

\begin{tabular}{crrr}
\hline \hline Variable & Coefficient & Std. Error & t-Statistic \\
\hline \hline C & 6530.389 & 626.3711 & 10.42575 \\
BI_X1___ & -2709.852 & 3399.235 & -0.797195 \\
DOLLAR_X2_ & -0.417051 & 0.074689 & -5.583821 \\
YUAN_X3_- & 0.317670 & 0.464702 & 0.683600 \\
DJ_X4_- & 0.212452 & 0.016379 & 12.97127 \\
SHANGHAI_X__ & 0.041210 & 0.062315 & 0.661309 \\
WTI_X6_- & -7.863732 & 2.271209 & -3.462355 \\
\hline \hline & & & \\
R-squared & 0.918744 & Mean dependent var \\
Adjusted R-squared & 0.909545 & S.D. dependent var \\
S.E. of regression & 175.1655 & Akaike info criterion \\
Sum squared resid & 1626196. & Schwarz criterion \\
Log likelihood & -391.3586 & Hannan-Quinn criter. \\
F-statistic & 99.87638 & Durbin-Watson stat \\
Prob(F-statistic) & 0.000000 & \\
\hline \hline
\end{tabular}

\section{F Statistical Test (Simultaneous Test)}

Based on the output display in the table above shows the F-statistic value of 99.87638 with a probability of 0.000 . Because the probability is far below 0.05 . it can be concluded that the six independent variables of BI, Dollar Exchange Rate, Yuan Exchange Rate, Dow Jones Exchange, Shanghai and WTI jointly (simultaneously) affect the CSPI. 


\section{$\underline{\text { R-squared (R2) Interpretation Test }}$}

Table 4.3. Information from Interpretation Analysis Results R-squared $\left(\mathrm{R}^{2}\right)$

\begin{tabular}{llll}
\hline \hline R-squared & 0.918744 & Mean dependent var & 5351.253 \\
Adjusted R-squared & 0.909545 & S.D. dependent var & 582.4147 \\
S.E. of regression & 175.1655 & Akaike info criterion & 13.27862 \\
Sum squared resid & 1626196. & Schwarz criterion & 13.52296
\end{tabular}

The table also shows the coefficient of determination (R2) of 0.918744 . This value shows that the five independent variables of BI, Dollar Exchange Rate, Yuan Exchange Rate, Dow Jones Exchange, and WTI were able to explain the effect of $91.8 \%$ on the IHSG dependent variable, while the remaining $8.2 \%$ was explained by factors other than the variables used in this study.

\section{Statistical Test t (Partial Test)}

Based on the estimation results in the table it can be explained that the exchange rate of the Dollar, the Dow Jones index and world crude oil prices have a significant effect, while the BI interest rate, the Yuan exchange rate and the Shanghai Index have no significant effect on the Composite Stock Price Index on the Indonesian stock exchange.

\section{Classic assumption test}

the classic assumption test is a test model that aims to make the regression model not biased or so that the BLUE (Best Linear Unlimited Estimator) regression model. (Gujarati and Sumarmo, 2003: 154).

1. Normality test

The following presents the results of the normality test by looking at the JarqueBera coefficient and Probability in Figure 4.3. :

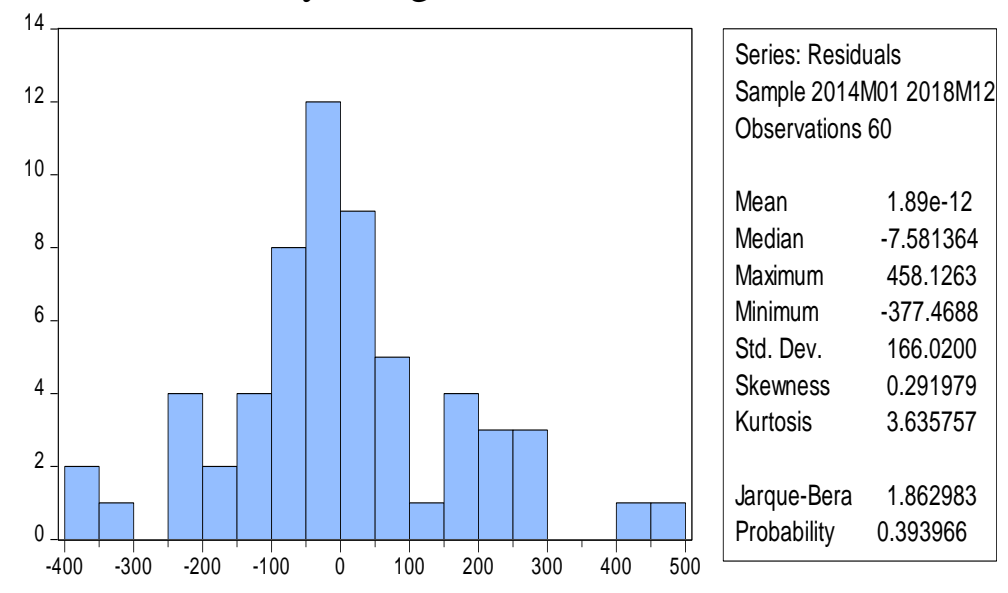

Figure 4.3. Normality Test Results

Based on the picture above it is known that the probability of Jarque-Bera is 0.393966. Because the p-value> Sig 0.05 then the data is normally distributed. So it can be concluded that the assumptions normally distributed in the model are met. 
2. Multicollinity Test

a. Calculates the value of Variance-Inflation Factor (VIF)

The occurrence of multicollinearity symptoms in a data in research can be known by observing the value of Variance-Inflation Factor (VIF). if the Centered VIF value $<10$ then multicollinearity does not occur. Conversely, if the Centered VIF value>10, then multicollinearity occurs. (Mardani, 2017).

From the data the researchers processed by using Eviews the results of their multicollinearity test see Table 4.4. as follows:

Table 4.4. Value of Variance-Inflation Factor (VIF)

\begin{tabular}{cccc}
\hline \hline Variable & $\begin{array}{c}\text { Coefficient } \\
\text { Variance }\end{array}$ & $\begin{array}{c}\text { Uncentered } \\
\text { VIF }\end{array}$ & $\begin{array}{c}\text { Centered } \\
\text { VIF }\end{array}$ \\
\hline \hline C & 392340.7 & 767.2159 & NA \\
BI_X1___ & 11554798 & 88.95221 & 4.069454 \\
DOLLAR_X2_ & 0.005578 & 1927.237 & 8.065985 \\
YUAN_X3_- & 0.215948 & 1764.791 & 4.685578 \\
DJ_X4_- & 0.000268 & 212.5148 & 5.562359 \\
SHANGHAI_X5_ & 0.003883 & 71.47069 & 2.280701 \\
WTI_X6_- & 5.158389 & 40.34710 & 3.690611 \\
\hline \hline
\end{tabular}

From Table 4.4. above shows that the values of Centered VIF both X1, X2, X3, X4, X5 and X6 are 4.069454, 8.065985, 4.685578, 5.562359, 2.280701 and 3.690611 where the value is less than 10 , it can be stated that there is no multicollinearity problem in the regression model.

b. Calculates the correlation coefficient between independent variables

From the data processed using the Eviews program, we get the correlation coefficient between variables as shown in Table 4.5 below.

Table 4.5. Intervariable Correlation Coefficient

\begin{tabular}{|c|c|c|c|c|c|c|}
\hline \multicolumn{7}{|c|}{ GG Group: UNTTILED Workfile: UNTTTLED:Untitled) } \\
\hline \multicolumn{7}{|c|}{\begin{tabular}{|l|l|l|l|l|} 
View Proc Object Print Name Freeze Sample Sheet Stats Spec \\
\end{tabular}} \\
\hline \multicolumn{7}{|c|}{ Correlation } \\
\hline & BI_X1_ & DOLLAR_X_ & YUAN_X3 & DJ XX_ & SHANGHAI_... & WTIXX_ \\
\hline BI_X1_ & 1.000000 & -0.453258 & -0.056168 & -0.773929 & -0.193501 & 0.239205 \\
\hline DOLLAR_X2_ & -0.453258 & 1.000000 & 0.766670 & 0.641146 & 0.400977 & -0.588196 \\
\hline YUAN XX & -0.056168 & 0.766670 & 1.000000 & 0.377851 & 0.478081 & -0.381715 \\
\hline DJ_X4 & -0.773929 & 0.641146 & 0.377851 & 1.000000 & 0.148794 & -0.091351 \\
\hline SHANGHAI_... & -0.193501 & 0.400977 & 0.478081 & 0.148794 & 1.000000 & -0.624008 \\
\hline WTI X6 & 0.239205 & -0.588196 & -0.381715 & -0.091351 & -0.624008 & 1.000000 \\
\hline
\end{tabular}

From Table 4.5. above it is known that the correlation value between independent variables is smaller than $0.8(\mathrm{r}<0.8)$ which means the model does not contain multicollinearity problems or the assumption that multicollinearity does not occur in the model are met.

c. Autokoleration Test

To eliminate autocorrelation, that is by first-level differentiation and BreuschGodfrey Test for first-level differentiation.

The following results from the analysis of equations with first-level differentiation: 


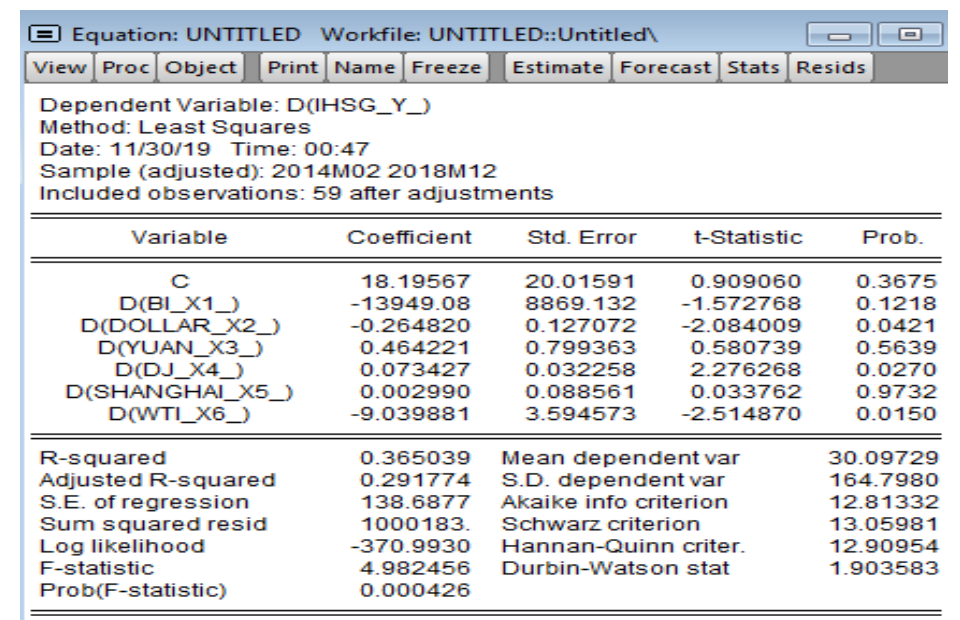

Figure 4.6. Results of Analysis of the Durbin-Watson Test Equation with Differentiation

From Figure 4.6. above D-W value $=1.903583$ shows that the regression model is free from autocorrelation symptoms.

\begin{tabular}{|c|c|c|c|c|}
\hline \multicolumn{4}{|c|}{$\equiv$ Equation: UNTITLED Workfile: UNTITLED::Untitled } & \multirow{2}{*}{ Resids } \\
\hline View [Proc [Object] [Print] & Name Freeze & Estimate] For & 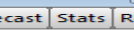 & \\
\hline \multicolumn{5}{|c|}{ Breusch-Godfrey Serial Correlation LM Test: } \\
\hline $\begin{array}{l}\text { F-statistic } \\
\text { Obs*R-squared }\end{array}$ & $\begin{array}{l}0.553798 \\
1.278640\end{array}$ & $\begin{array}{l}\text { Prob. } F(2,50) \\
\text { Prob. Chi-Sq }\end{array}$ & are(2) & $\begin{array}{l}0.5782 \\
0.5277 \\
\end{array}$ \\
\hline \multicolumn{5}{|c|}{ 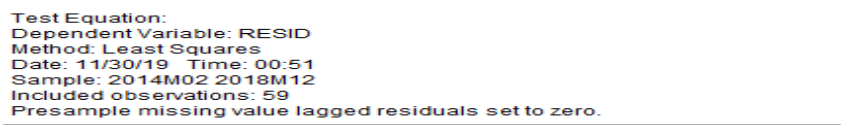 } \\
\hline Variable & Coefficient & Std. Error & t-Statistic & Prob. \\
\hline 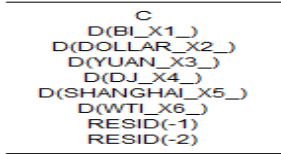 & $\begin{array}{r}-0.236541 \\
1480.291 \\
0.026682 \\
-0.163718 \\
0.001640 \\
-0.002863 \\
-0.118969 \\
0.022359 \\
0.156673 \\
\end{array}$ & $\begin{array}{l}20.20733 \\
9056.453 \\
0.133649 \\
0.843867 \\
0.032576 \\
0.089411 \\
3.684095 \\
0.152020 \\
0.150020\end{array}$ & $\begin{array}{r}-0.011706 \\
0.163452 \\
0.199640 \\
-0.194009 \\
0.050338 \\
-0.032016 \\
-0.032293 \\
0.147081 \\
1.044344 \\
\end{array}$ & $\begin{array}{l}0.9907 \\
0.8708 \\
0.8426 \\
0.8470 \\
0.9601 \\
0.9746 \\
0.9744 \\
0.8837 \\
0.3013 \\
\end{array}$ \\
\hline $\begin{array}{l}\text { R-squared } \\
\text { Adjusted R-squared } \\
\text { S.E. of regression } \\
\text { Sum squared resid } \\
\text { Log likelihood } \\
\text { F-statistic } \\
\text { Prob(F-statistic) }\end{array}$ & $\begin{array}{r}0.021672 \\
-0.134861 \\
139.8933 \\
978507.0 \\
-370.3466 \\
0.138450 \\
0.997021\end{array}$ & \multicolumn{2}{|c|}{$\begin{array}{l}\text { Mean dependent var } \\
\text { S.D. dependent var } \\
\text { Akaike info criterion } \\
\text { Schwarz criterion } \\
\text { Hannan-Quinn criter. } \\
\text { Durbin-Watson stat }\end{array}$} & $\begin{array}{l}-4.82 E-15 \\
131.3184 \\
12.85921 \\
13.17612 \\
12.98292 \\
1.892867\end{array}$ \\
\hline
\end{tabular}

Figure 4.7. Breusch-Godfrey Test of Residuals

From Figure 4.7. the results of data analysis above the value of prob X2>5\% indicate that the model is free from autocorrelation symptoms. So it can be concluded that the equation model does not experience autocorrelation problems.

\section{d. Heteroscedasticity Test}

If there are certain patterns such as dots that form a certain regular pattern, it indicates heteroscedasticity. If there is no clear pattern, and the points that spread above and below the zero on the Y axis then indicate no heteroscedasticity. (Witjaksono, 2010: 113).

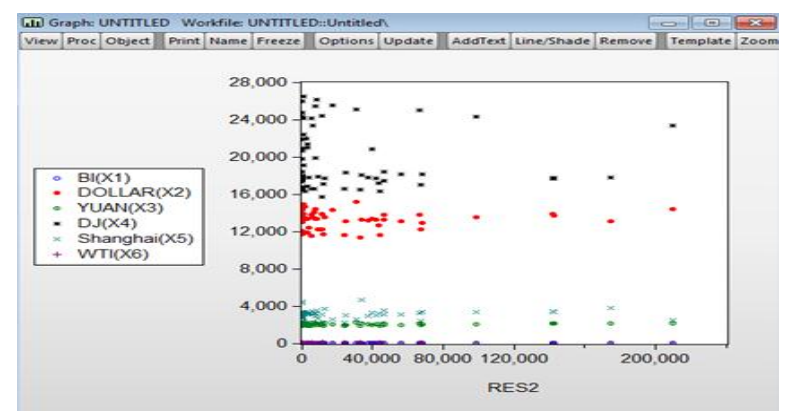

Figure 4.8. Heteroscedasticity Test Results Graph Method 
Based on the scatter graph test, the interpretation of the scatterplot above shows that the scattered data follows a certain pattern, so the author suspects that there might be no heteroscedasticity problems in the model. In other words, the regression model is homoscedasticity or has the same variance. Although it looks easy, to reinforce confidence in the conclusion of the data test above, the author conducts further data testing using the Breusch-pagan-Godfrey Test method and the Glejser Test.

\section{Breusch-pagan-Godfrey Test}

Here is a picture displaying the results of the Heteroscedasticity Test: Breusch-PaganGodfrey

Table 4.6. Heterokedasticity Test Results: Breusch-Pagan-Godfrey

\begin{tabular}{|c|c|c|c|c|}
\hline $\begin{array}{l}\text { F-statistic } \\
\text { Obs } \\
\text { Scaled-squared explained SS }\end{array}$ & $\begin{array}{l}1.252090 \\
7.448909 \\
7.659796 \\
\end{array}$ & \multicolumn{2}{|c|}{$\begin{array}{l}\text { Prob. F(6,53) } \\
\text { Prob: Chi-Square(6) } \\
\text { Prob. Chi-Square(6) }\end{array}$} & $\begin{array}{l}0.2953 \\
0.2813 \\
0.2641 \\
\end{array}$ \\
\hline \multicolumn{5}{|c|}{$\begin{array}{l}\text { Test Equation: } \\
\text { Mependent Variable: RESID^2 } \\
\text { Method: Least Squares } \\
\text { Date: 11/30/19 Time: } 1: 24 \\
\text { Sample: 2014Mo12018M12 } \\
\text { Included observations: } 60\end{array}$} \\
\hline Variable & Coefficient & Std. Error & t-Statistic & Prob. \\
\hline 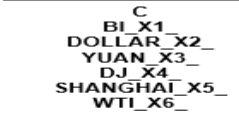 & $\begin{array}{l}7666.161 \\
1440878 . \\
-17.81889 \\
71.41686 \\
5.671766 \\
-9.404164 \\
-1038.428\end{array}$ & $\begin{array}{l}156678.9 \\
850276.0 \\
18.68255 \\
116.2393 \\
4.096922 \\
15.58738 \\
568.1144\end{array}$ & $\begin{array}{r}0.048929 \\
1.694601 \\
-0.953772 \\
0.614395 \\
1.384397 \\
-0.603319 \\
-1.827850\end{array}$ & $\begin{array}{l}0.9612 \\
0.0960 \\
0.3445 \\
0.5416 \\
0.1720 \\
0.5489 \\
0.0732\end{array}$ \\
\hline $\begin{array}{l}\text { R-squared } \\
\text { Adjusted R-squared } \\
\text { S.E. of regression } \\
\text { Sum squared resid } \\
\text { Log likelihood } \\
\text { F-statistic } \\
\text { Prob(F-stistic) }\end{array}$ & $\begin{array}{l}0.124148 \\
0.024995 \\
43815.44 \\
1.02 E+11 \\
-722.6792 \\
1.252090 \\
0.295329\end{array}$ & \multicolumn{2}{|c|}{$\begin{array}{l}\text { Mean dependent var } \\
\text { S.D. dependent var } \\
\text { Akaike info criterion } \\
\text { Schwarz criterion } \\
\text { Hannan-Quinn criter. } \\
\text { Durbin-Watson stat }\end{array}$} & $\begin{array}{l}27103.27 \\
44373.52 \\
24.32264 \\
24.56698 \\
24.41822 \\
1.606577\end{array}$ \\
\hline
\end{tabular}

Breusch-pagan-Godfrey test results indicate that there was no heteroscedasticity in the WLS results indicated by the value of Obs * R-Squared which was not statistically significant ( $\mathrm{p}$ value $=0.2813$ ). This shows that the model is homoscedastic or it can be assumed that the model does not contain heteroscedastic fulfillment.

\section{Glejser Test}

The output of the Glejser Test results is as follows:

\begin{tabular}{|c|c|c|c|c|c|c|c|c|c|}
\hline \multicolumn{4}{|c|}{$\equiv$ Equation: UNTITLED } & \multicolumn{4}{|c|}{ Workfile: UNTITLED::Untitled } & \multicolumn{2}{|c|}{ 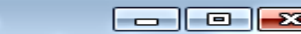 } \\
\hline View & Proc & Object & Print & Name & Freeze & Estimate & Fore & ecast Stats & Resids \\
\hline \multicolumn{10}{|c|}{ Heteroskedasticity Test: Glejser } \\
\hline \multirow{3}{*}{\multicolumn{4}{|c|}{$\begin{array}{l}\text { F-statistic } \\
\text { Obs*R-squared } \\
\text { Scaled explained ss }\end{array}$}} & \multirow{2}{*}{\multicolumn{2}{|c|}{$\begin{array}{l}1.013656 \\
6.176442\end{array}$}} & \multicolumn{3}{|c|}{ Prob. F(6,53) } & 0.4265 \\
\hline & & & & & & \multirow{2}{*}{\multicolumn{3}{|c|}{$\begin{array}{l}\text { Prob. Chi-Square(6) } \\
\text { Prob. Chi-Square(6) }\end{array}$}} & 0.4037 \\
\hline & & & & \multicolumn{2}{|c|}{6.984038} & & & & 0.3223 \\
\hline \multicolumn{10}{|c|}{$\begin{array}{l}\text { Test Equation: } \\
\text { Dependent Variable: ARESID } \\
\text { Method: Least Squares } \\
\text { Date: } 11 / 30 / 19 \text { Time: } 01: 48 \\
\text { Sample: } 2014 M 012018 M 12 \\
\text { Included observations: } 60\end{array}$} \\
\hline \multicolumn{4}{|c|}{ Variable } & \multicolumn{2}{|c|}{ Coefficient } & \multicolumn{2}{|c|}{ Std. Error } & t-Statistic & Prob. \\
\hline \multicolumn{4}{|c|}{$\mathrm{c}$} & & \multirow{2}{*}{\multicolumn{2}{|c|}{$\begin{array}{l}404.6176 \\
2195.807\end{array}$}} & 0.509584 & 0.6125 \\
\hline \multicolumn{4}{|c|}{$\mathrm{Bl}_{1} \mathrm{x}_{1}$} & & & & & \multirow{2}{*}{$\begin{array}{r}1.415778 \\
-1.300039\end{array}$} & 0.1627 \\
\hline \multirow{2}{*}{\multicolumn{4}{|c|}{$\begin{array}{l}\text { DOLLAR_X2 } \\
\text { YUAN_X3_- }\end{array}$}} & \multicolumn{2}{|c|}{$\begin{array}{r}3108.776 \\
-0.062723\end{array}$} & \multicolumn{2}{|c|}{0.048247} & & 0.1992 \\
\hline & & & & \multicolumn{2}{|c|}{0.251103} & \multicolumn{2}{|c|}{0.300184} & $\begin{array}{r}-1.300039 \\
0.836498\end{array}$ & 0.4066 \\
\hline \multicolumn{4}{|c|}{ DJ_ $\bar{x} 4$} & \multicolumn{2}{|c|}{0.013753} & \multicolumn{2}{|c|}{0.010580} & 1.299894 & 0.1993 \\
\hline \multicolumn{4}{|c|}{$\begin{array}{l}\text { SHANGHAI_ } \times 5 \\
\text { WTI } \times 6\end{array}$} & \multicolumn{2}{|c|}{-0.026087} & \multicolumn{2}{|c|}{0.040254} & -0.648061 & 0.5197 \\
\hline & wT & $T 1 \_6_{2}^{-}$ & & -2.51 & 12309 & 1.46713 & 35 & -1.712391 & 0.0927 \\
\hline R-sq & guarec & & & 0.10 & 02941 & Mean dep & pend & lent var & 120.3987 \\
\hline Adju: & sted $\mathrm{F}$ & R-square & & 0.00 & 01387 & S.D. depe & ende & nt var & 113.2304 \\
\hline S.E. & of reg & ression & & 113. & 1518 & Akaike inf & fo $\mathrm{cr}$ & iterion & 12.40462 \\
\hline sum & squa & ared resid & & 678 & 3576.7 & Schwarzo & crite & rion & 12.64896 \\
\hline $\log 1$ & likelin & lood & & -365 & 5.1386 & Hannan-C & Quin & n criter. & 12.50019 \\
\hline F-sta & atistic & & & 1.01 & 13656 & Durbin-w & Vatsc & on stat & 1.718281 \\
\hline Prob & (F-sta & atistic) & & 0.42 & 26533 & & & & \\
\hline
\end{tabular}

Figure 4.9. Heteroscedasticity Glejser Test 
The results of the output display above show that the variables BI, Dollar, Yuan, Dow Jones, Shanghai and WTI are not significant at 0.05 , which indicates there is no heteroscedasticity in the regression model. Therefore, it can be concluded that the regression model is free from symptoms of heteroscedasticity.

\section{CONCLUSION AND SUGGESTION}

\section{Conclusion}

From the classical assumption test results, it can be concluded that the analysis of the normality of residual data distribution assumption is normal, in the heteroskedasticity test there is no heteroscedasticity problem in the model, the multicollinearity test of the regression model does not contain multicollinearity problems or the assumption does not occur multicollinearity in the model is fulfilled, in the autocorrelation test the regression model is free from autocorrelation symptoms and regression models are feasible to use. The results showed that BI, Dollar Exchange, Yuan Exchange, Dow Jones, Shanghai and WTI were able to explain the effect of $91.8 \%$ on the IHSG dependent variable. While the rest is explained by other variables outside the model. BI's six independent variables, Dollar Exchange Rate, Yuan Exchange Rate, Dow Jones Exchange, Shanghai and WTI jointly (simultaneously) significantly influence the CSPI on the IDX. After conducting a regression analysis and statistical testing it can be concluded that the BI 7 Day variable, the Yuan and Shanghai exchange rates have no significant effect on the CSPI at the level of 0.05 . While the variable exchange rate of the Dollar, the Dow Jones Index and world crude oil (WTI crude oil) have a significant influence on the CSPI at the level of $=0.05$ with coefficients of respectively $0.41705,+0.21245$ and -7.86373 . Based on the ranking of the significance and regression coefficient values of the research variables, the Crude Oil (WTI) variable is the most dominant variable affecting the Composite Stock Price Index (CSPI) on the Indonesia Stock Exchange.

\section{Suggestions}

Macroeconomic variables are proven to influence the movement of the composite stock price index on the Indonesia Stock Exchange, so for investors and prospective investors who will invest in the capital market in Indonesia need to be aware of the movement of the dollar exchange rate, the movement of the Dow Jones Index and world crude oil prices in considering investment decisions. For companies listing on the Indonesia Stock Exchange (IDX) it is necessary to be aware of movements in the dollar exchange rate, dow jones index and world oil prices because they have an influence on company performance.

\section{REFERENCE}

Amin, Muhammad Zuhdi. (2012)."Pengaruh Tingkat Inflasi, Suku Bunga SBI, Nilai Kurs Dollar (USD/IDR), Dan Indeks Dow Jones (DJIA) terhadap Pergerakan Indeks Harga Saham Gabungan Di Bursa Efek Indonesia (BEI)". Jurnal Faculty Economic and Bisnis Universitas Brawijaya, hal. 1-17.

Anggoro, Tri susilo. (2011). "Pengaruh Inflasi, Kurs dan Suku Bunga SBI terhadap Indeks Harga Saham Gabungan (IHSG) di BEI". Skripsi. Fakultas Ekonomi, Universitas Sebelas Maret. Surakarta. 
Anonim. (2018). Minyak Bumi Brent (Brent Crude) dan WTI (West Texas Intermediate Crude). [Online] Available: http://primaplastindo.co.id/minyak-brent-wti/ (October 27, 2019).

(2018). Indeks Harga Saham. Bursa Efek Indonesia. Jakarta. [Online] Available: https://www.idx.co.id/produk/indeks/ (May 31, 2019)

. (2019). BI 7-day (Reverse) Repo Rate. Bank Indonesia. Jakarta. [Online] Available: https://www.bi.go.id/id/moneter/bi-7day-RR/data/Contents/Default.aspx (May 31, 2019)

(2019). Pengertian dan Fungsi BI Rate dan BI 7-Day (Reverse) Repo Rate. [Online] Available:https://www.simulasikredit.com/pengertian-dan-fungsi-bi-rate-dan-bi-7-day-reverserepo-rate/ (May 31, 2019)

(2018). Mengenal Teori signaling dalam struktur modal. [Online] Available: https://www.jurnal.id/id/blog/2018-mengenal-teori-signaling-dalam-struktur-modal// July 20, 2019)

(2019). Indeks Komposit SSE. [Online] Available: https://id.wikipedia.org/wiki/Indeks_Komposit_SSE. (November 27, 2019).

(2019). BI Naikkan Suku Bunga Acuan 6 Kali di 2018, dari 4,5\% Jadi 6\%. [Online] Available: https://economy.okezone.com/read/2018/12/20/20/1994005/bi-naikkan-suku-bungaacuan-6-kali-di-2018-dari-4-5-jadi-6. (November 28, 2019).

Astuti, Rini; Joyce Lapian, dan Paulina Van Rate. (2016). "Pengaruh Faktor Makro Ekonomi Terhadap Indeks Harga Saham Gabungan (IHSG) Di Bursa Efek Indonesia (BEI) Periode 2006-2015”. Jurnal Berkala Ilmiah Efisiensi, Vol. 16, No. 02, hal 399-406.

Djamaluddin, Said., Diny Rahmawati., dan HapziAli. (2017). "The Influence of Fundamental Factors Micro and Macro to Return Expected Through The Intervening Corporate Value in The Listed Real Estate Sectorr in Bei Periode 2011-2014". International Journal of Business Management.Vol. 6, Issue 2, hal. 14-22.

Djamaluddin, Said., Muhammad Rizki., dan Apollo. (2018). "Analysis of the Influence of Macro Economic Factors against JCI Return in Indonesia Stock Exchange". International Journal of Innovative Research and Development (IJIRD). Vol. 7, issue 2, hal. 208-217.

Ernayani, Rihfenti. (2015). "Pengaruh Kurs Dolar, Indeks Dow Jones Dan Tingkat Suku Bunga SBI Terhadap IHSG”.Jurnal Sains Terapan, No.2, Vol. 1, Hal 108-114.

Ghozali, Imam dan Dwi Ratmono. (2017). Analisisn Multivariat dan Ekonometrika teori,konsep dan Aplikas dengan Eviews 10. Edisi 2. Fakultas ekonomi dan Bisnis Universitas Diponegoro. Semarang.

Gujarati, Damodar dan Sumarno, Zain. (2003). Ekometrika Dasar. Jakarta: Erlangga.

Kewal, Suramaya Suci (2012). "Pengaruh Inflasi, Suku Bunga, Kurs, dan Pertumbuhan PDB terhadap Indeks Harga Saham Gabungan”. Jurnal Economia, Vol. 8, No. 1, hal. 53-64.

Kurnianto, $\quad$ Adi. (2015). Teori asimetri informasi. https://superkurnia.wordpress.com/2015/09/11/teori-asimetri-informasi/ (20 juli 2019)

Puspita, Shindi. (2019). [Online] Available: https://www.academia.edu/35296500/ARBITRAGE PRICING THEORY APT (July 20, 2019).

Setiawan, Sakina Rakhma Diah. (2018). China Masih Jadi Mitra Dagang Utama Indonesia. [Online] Available:https://ekonomi.kompas.com/read/2018/02/15/150506126/china-masih-jadi-mitradagang-utama-indonesia (July 1, 2019).

Tarigan, Razaq Dastanta., Suhadak., dan Topowijono. (2015). "Pengaruh Indeks Harga Saham Global Terhadap Indeks Harga Saham Gabungan (Ihsg) Studi Pada Bursa Efek Indonesia (Bei) Periode 2011-2014”. Jurnal Administrasi Bisnis (JAB). Vol. 24, No. 1. 
Triyono. (2008). "Analisis Perubahan Kurs Rupiah terhadap Dollar Amerika". Jurnal Ekonomi Pembangunan, Vol. 9, No. 2, hal. 156 - 167.

Winarno, Wing Wahyu. (2017). Analisa Ekonometrika dan Statistika dengan Eviews. Edisi 5. Unit Penerbit dan Percetakan STIM YKPN. Yogyakarta.

Witjaksono, Ardian Agung. (2010). “Analisis Pengaruh Tingkat Suku Bunga SBI, Harga Minyak Dunia, Harga Emas Dunia, Kurs Rupiah, Indeks Nikkei 225, dan Indeks Dow Jones terhadap IHSG". Tesis. Program Studi Magister Manajemen, Program Pascasarjana. Universitas Diponegoro. Semarang.

Yugo, Galuh. (2019). [Online] Available: http://galuhyugounipma.blogspot.com/2017/12/vbehaviorurldefaultvmlo.html (July 20, 2019). 